\title{
AN APPLICATION OF THE CORPORATE COMPANY MODELS FOR SOCIAL ENTERPRISE (WITH SPECIAL EMPHASIS ON POLISH CONDITIONS)
}

\section{MAŁGORZATA KURLETO}

\begin{tabular}{|c|c|}
\hline & $\begin{array}{l}\text { Jagiellonian University } \\
\text { e-mail: m.kurleto@uj.edu.pl }\end{array}$ \\
\hline $\begin{array}{l}\text { RECEIVED } \\
\text { ACCEPTED }\end{array}$ & $\begin{array}{l}23 \text { March } 2015 \\
1 \text { June } 2015\end{array}$ \\
\hline $\begin{array}{l}\text { JEL } \\
\text { CLASSIFICATION }\end{array}$ & $\mathrm{C} 52, \mathrm{~K} 29, \mathrm{M} 48$ \\
\hline KEYWORDS & corporate company models, business model, social enterprise \\
\hline ABSTRACT & $\begin{array}{l}\text { This study seeks to answer the fundamental question referring to opportunity of employing for social enterprise } \\
\text { - company models and strategies to maximize improvements in human and environmental well-being (rather } \\
\text { than producing profits for owners and shareholders). This analysis was limited to presenting only certain as- } \\
\text { pects of the adaptation of the experience of models derived from the for-profit model for social enterprise. The } \\
\text { paper is focusing on the major conceptual, strategic and legal issues referring to social enterprises (especially } \\
\text { in terms and conditions opportunities that exist in Poland). The scope of this study includes, in particular, explor- } \\
\text { ing the possibilities for using of the business models and some of the process models for social enterprise. }\end{array}$ \\
\hline
\end{tabular}

\section{Introduction}

Social enterprises are searching for new models to enable them to fulfil their missions. A new business models and strategies for social enterprises can be transferred from company models. However, in practice it is not always suited to their proven models of operation and therefore new strategies and methods demand a new innovative approach (Kurleto, 2014). 
This study prior to wider research conducted by the author in this field is to answer the fundamental question of whether (and how) the possibilities and limitations exist with the use of the experience of corporate companies for social enterprises. This analysis will be only limited to certain aspects of the present issues particularly relating to the understanding of traditional and social enterprises and key strategic issues, models (including company's business and process models) and legal forms especially referred to the Polish experience (Gołębiowski et al., 2008).

\section{The essential differences in the understanding of the corporate companies and social enterprises business model}

A company is a separate legal entity capable of holding assets in its own name with an aim of gaining a profit. Corporate company models include: business models, operating models, business process modelling as well models of organizational structure. A company is a complex system. An operating model breaks this system into components, showing how it works. By contrast, a business model describes how an organization creates, delivers and captures value and sustains itself in the process. There is a basic dichotomy at play in the use and deployment of corporate models. Business process modelling, often called process modelling is the analytical representation or illustration of an organization's business processes. (A business process is an activity or set of activities that will accomplish a specific organizational goal). Companies select as well models of organizational structure depending on their size, marketing strategy and industry.

A corporate company:

- seeks to maximize its value to investors,

- operates in the market of business transactions to generate profit,

- operating in a competitive global economy,

- has achieved profits of material benefits.

In contrast, a social enterprise:

- aims to create social change by solving social problems,

- strives to meet the needs of society in a sustainable way,

- basically works to the beneficiaries,

- assesses the profits generated by the social utility and economic efficiency of the company.

The comparison shows that the social enterprise pursues social objectives while corporate businesses are oriented to economic goals. On the other side, however, is increasingly rare today to identify the corporate business activity only (Grewiński and Wronka, 2012).

According to J. Schumpeter, entrepreneurship is the perception of the opportunities of the projects profitable and risk-taking in their implementation (Stevenson and Jarillo, 2007). Without these qualities economy activity is not a manifestation of entrepreneurship, and the organization is hardly a company.

The word social simply modifies the meaning of the word entrepreneurship. The attribute community indicates on the one hand to the basic resources that utilizes the company, on the other hand on his mission. The essential distinction between business entities and social enterprises lies in the proposed offer.

The business entity seeks to obtain financial gain. The purpose of a social entrepreneur is a value in the form of benefits, which carry the changes that society as a whole, or a substantial part of it. This does not mean that the iron rule of social entrepreneurs is the avoidance of tenders profitable. Measures of social entrepreneurs can 
certainly generate income. The main goal of social entrepreneurship is to create social value proposition through innovation, risk management and pro-active social mission, sustainable development and environmental protection (Weerewardena and Mort, 2006: 21-25).

Nowadays it is possible to observe the dissemination of economization of the NGO sector, which is increasingly conformed to the business sector when it comes to organizational issues, customer acquisition, property management and resources (Grewiński and Wronka, 2012). It should be noted that the activities of social enterprises directly affects the satisfaction of social needs. This distinguishes them from socially responsible companies that create positive social change indirectly through the practice of corporate social responsibility (Kurleto, 2013).

Components of business model of corporate company can be adopted from Newth (2012).

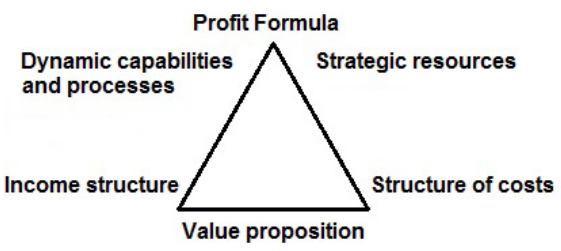

Figure 1. Components of business model of corporate company

Source: adopted from Newth (2012) as well Brzóska and Jerzok (2014: 67).

Components of social enterprise business model can be adopted from Brzóska \& Jerzok (2014).

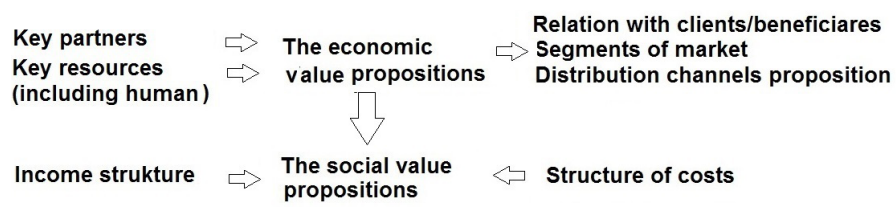

Figure 2. Components of social enterprise business model

Source: own elaboration based on Brzóska and Jerzok (2014: 69).

Comparison of both models (commercial business model to social enterprise business model) show that the business model includes dynamic capabilities and processes and strategic resources while in the social enterprise model the most important elements are: key partners, key resources and relation with clients/beneficiaries (Brzóska and Jerzok (2014) presented the examples of the social enterprise model in Poland based on social cooperative model).

The business model has shape of triangle (emphasising importance of profit) while the rectangle shape of a social enterprise business is based on feedback compression. 
An issue of social enterprise business models is presented by Czemiel-Grzybowska (2010: 120-121). The cited author emphasised specific nature of social enterprise business models, which are resulted from: formulated social goals realized through the achievement of economic goals (which include bearing of the economic risk). The cited author emphasised weakness of social business model. In particular, by preference social goals can be considered them more defective on competitive market.

\section{Possibilities of using commercial models to social enterprises}

\section{The chances of application business models}

In the literature, there is no generally accepted definition of one business model. The most synthetic concepts are those that focus on cash flows: business model is the answer to the question: where and how to make money? (Magretta, 2003: 57). Koźminski and Piotrowski (2005: 123) stated that: business model it is the idea of making money by the company. Business model which is the starting point for achieving sustainable competitive advantage should not be confused with the strategy of the organization, although there are between these concepts essential connections and similarities (Drzewiecki, 2011: 337). Obłój (2002: 98-100). expresses opinion that the business model is the concept of the system which includes: the three main components: a dominant competitive advantage (natural, relational, operating system, barriers to entry), the main resources and skills of the company and the configuration of the value chain.

The business model contain a description of the value offered by the company group or groups of clients, including the definition of basic resources, processes (activities), as well as the external relations of the company, for creating, offering and delivering value for customers/beneficiaries and achieving a competitive advantage position relative to its business. (Gołębiowski et al., 2008: 57).

According to Osterwalder and Pigneur (2010: 14) business model consists of nine basic elements, which are in line with the process of making money by the company. These nine elements affect the four main areas of business, clients, offers, infrastructure and adequate financial position: 1) Target customer segments; 2) Configuration of the proposals, which describes a system of activities and resources available; 3) Communication channels of distribution and sales; 4) Relations with clients from various segments; 5) Streams of income (realization value proposition); 6) Key resources are assets necessary for the formulation and implementation of items 1-5; 7) Key actions that describe how a company makes money; 8 ) Key partners network, which shows cooperation agreements with other organizations that are necessary to effectively function; 9) The cost structure.

The elements of the business model show similarity to the concept of the enterprise's key success factors (Wronka, 2013: 2-3). However it seems that application of the business models, which take into account: issues of value proposition, key resources and costs, donate throughout the holistic nature of the structure and operation of the process of social enterprises can bring more effective possibilities in terms of achieving economic and social value than is apparent from concept of the enterprise's key success factors.

It should be emphasised that there is no need for expanding the number of elements of business models for social enterprises (as has been done in the thirteen - membered Michelini model (2012) because it can lead to misunderstandings. The business model of social entrepreneurship needs the inclusion only of certain elements in the field of process models, organizational and marketing (Bednarczyk, 1996).

It seems that the analysis of social enterprise business models highlighted: value of the proposed offer, evaluation of resources, channels of distribution, relationships with customers, content network, the revenue model 
and the environmental assessment of this competition (Effective evaluation of the enterprise environment can be done by a structural analysis of the sector (Bednarczyk, 2001).

Analysis of social enterprise business models should take into account the most versatile exploration in this regard made by Kim Alter (2008). The cited author stated that social enterprise can be combined with a nonprofit organization, in different ways: "Embedded within, Embedded externally or Integrated" (Alter, 2008: 169-197) According to the Alter (2008: 169-197) successful achievement of the social enterprise model is dependent on the degree of integration between the implementation of social programs and activities on the market also is determined by different kind of "Embedding".

In social enterprises are used business solutions to meet social goals. A social enterprise business model should contain two key elements (Social Enterprise business models, 2009): 1) an operating strategy covering the internal organization (structure) and external partnerships that are crucial for creating the organization's intended impact; 2) a resource strategy relating to the existence and proper use of financial and human resources.

The business model for a social enterprise is the channel that the social entrepreneur converts inputs into outcomes (Balan Vnuk, 2013).

According to the opinion of Foster, Kim and Christiansen (2009) rules that govern business and business models do not apply to social enterprises in the non-profit sector. Instead of the business model the authors propose the use of the so-called founding model. Not everyone agrees with this point of view. Saul Kaplan (2012) in 2005, began testing innovative business models for social enterprises. According to Kaplan the business model is description of how the social enterprise has been in business, how they arranged themselves relationships with business partners and customers as well how to make profit from its activities.

Reflecting the application of corporate companies business models in social enterprises should be noted that: these entities do not generate financial returns to investors and owners, but carry out its mission also need a stable business model to achieve success (Kaplan, 2013).

\section{Opportunity of the use others corporate company models}

Referring to the possibility of using others (than business models) corporate company models for social enterprises should be noted that in this area may be taken into account in particular the concepts of the entrepreneurial process.

Presentation of the entrepreneurial process, however, is particularly difficult due to the more dynamic, holistic, uniqueness, discontinuity and variability.

The dependence on a number of variables and a high sensitivity to changes in their value is included in the process of entrepreneurial activity, which can be conceptualized as a function of opportunity structures and motivated entrepreneurs. This process starts with the identification of ideas and runs through a phase identification, development, evaluation, and implementation or rejection of the opportunity.

The business process model stands out the following features: The business Process Model, 2004) 1) Has a Goal; 2) Has specific inputs; 3) Has specific outputs; 4) Uses resources; 5) Has a number of activities that are performed in some order; 6) May affect more than one organizational unit; 7) Creates value of some kind for the customers / beneficiaries (internal or external).

Morris, Lewis and Sexton (1994: 21-31) attempt to integrate different approaches to the process of entrepreneurship based on the relationship between inputs and outputs. 
It seems to that this model can be used for social enterprise. This model contains three elements:

- Input, which include key business factors,

- Entrepreneurial process, including the identification of opportunities,

- Exit action, which include creation of value (economic and social) employment.

Model of Antoszkiewicz (similar to the model of Morris, Lewis, and Sexton), is based on the separation of input, process and output. Entrepreneurship in this model comes from the idea, which meets social needs with organizations and practical action. (involving risk). The social business can be considered as a process, which is the result of specific interactions between organizational attributes of people and some kind of event as a stimulant: 1) features of the organization (management support, rewards, gain, availability of time, the limits of the organization; 2) individual characteristics (propensity to take risks, striving for autonomy, focus on goals).

The entrepreneurial activity mentioned in model of Antoszkiewicz depends not only on internal factors but also on external factors (political, legal regulations, cultural background).

Social entrepreneurship is created in the process of optimizing a system consisting of tangible and intangible factors using practical reasons to guide the ultimate goal of meeting social needs. Activities of social enterprises are dependent on the social "consent". In case of social enterprises direct feedback in the form of cash flow does not occur (Ćwiklicki, 2011). Hence there is a need to care about the source of legitimacy and support.

\section{Social enterprises (and their business models) with special emphasis on the Polish conditions}

The interest in social enterprise in Poland as an instrument of social policy began after 1989 as a result of structural changes in the democratic system. Social entrepreneurship has been introduced as a phenomenon that provides innovative solutions to the most difficult social problems such as poverty, health, education, unemployment, social exclusion and environmental protection (Van Slyke, 2006: 345-372).

In Poland, social entrepreneurships widely consider commercial rules of the business. In various aspects they regulate through more than 120 Acts (Schimanek, 2010). These regulations establish the basic terms and conditions of business, regardless of the legal form in which it is carried out and also the ownership structure of the entity conducting it. The first crucial Act for opening social businesses in Poland was Act of 13 June 2003. Social Employment (Journal of Laws 2003, No. 122, item. 1143, as amended. D). The Act of 27 April 2006 on Social Cooperatives, (2006 No. 94, item. 651, as amended) announced rules for the conduct of social cooperatives. Comparing the legal regulations of business entities and social enterprises it should be noted, that special forms of state support are provided mainly for social cooperatives. In other cases, social enterprises use these forms of direct support (grants) or indirect (exemption from public contributions, preference in applying for public contracts), which are available for NGOs. The project of 2015 Law on Social Enterprise in Poland does not introduce any new legal form allows to obtain in court the status of a social enterprise. (Projekt ustawy o przedsiębiorstwie społecznym, 2015) This project sees as the main objective of social enterprises reintegration of the unemployed, other excluded groups and disability people. The project emphasises that activity o social enterprises should include: social assistance, childcare, education services in the field of child care.

Social entrepreneurship will be entitled to special rights, including benefit from the support of public programs, exemption from corporate income tax, property tax, reduced VAT rate, and preference in applying for public contracts, use of volunteer labour. Recognizing the diversity of the Polish socio-economic conditions requires not accept uncritically Alter's classification of models. The author of this paper, is standing on the position that the 
cooperatives, besides social cooperative (based on Act of 27 April 2006 on Social Cooperatives), doesn't belong to the category of social enterprises.

As examples of the use of business models for social enterprises in Poland can be presented in the table below:

Table 1. Social enterprise business model examples (in Poland)

\begin{tabular}{lll}
\hline \multicolumn{1}{c}{ Business model } & \multicolumn{1}{c}{ How it works } & \multicolumn{1}{c}{ Examples } \\
\hline $\begin{array}{l}\text { Fundraising - } \\
\text { entrepreneurial mix }\end{array}$ & $\begin{array}{l}\text { Provide social and economic activity based on fundraising } \\
\text { founds (Osterwalder A. \& Pigneur Y. 2010) }\end{array}$ & $\begin{array}{l}\text { Based most often on Canvas model } \\
\text { (spolecznystartup.pl /form/formularz_kategoria_1.docx) }\end{array}$ \\
\hline Placement and support & $\begin{array}{l}\text { Provide services to clients to help them access markets. } \\
\text { Micro-financial enterprise } \\
\text { (http://erasmusplus.org.pl/) }\end{array}$ \\
\hline $\begin{array}{lll}\text { Social Cooperative } \\
\text { - for employment }\end{array}$ & $\begin{array}{l}\text { Provide employment opportunity for disabled people, } \\
\text { the homeless, ex-offenders, and young people }\end{array}$ & Social Cooperative based on Act of 27 April 2006 \\
\hline $\begin{array}{l}\text { Social entrepreneur } \\
\text { - market player }\end{array}$ & $\begin{array}{l}\text { Activities based mainly on the authority and ability } \\
\text { of the individual entrepreneur }\end{array}$ & Fundacja Wielka Orkiestra Światecznej Pomocy \\
\hline $\begin{array}{l}\text { Philanthropic operator } \\
\text { - working in network }\end{array}$ & $\begin{array}{l}\text { Social enterprise belongs to a charity or a foreign national } \\
\text { network of philanthropic enterprises (venture philanthropy) }\end{array}$ & $\begin{array}{l}\text { Ashoka } \\
\text { (Ashoka Polska. Innowatorzy dla dobra publicznego, 2013) }\end{array}$ \\
\hline
\end{tabular}

Source: own elaboration.

It seems that a social enterprise on the Polish conditions must be built as a robust, integrated network, which includes the default local node. Social enterprises have to pick up signals about the need by potential beneficiaries of support and process the information efficiently. It should be emphasised that in discussing of the differentials between corporate companies and social business models special attention is usually given to: mission, resources and performance measurement (Pynes, 2011).

\section{Conclusions}

Social enterprises can use business solutions for social problems. Social enterprise employs business strategies to improve human and environmental well-being, rather than producing profits. The majority of profits from the associated social enterprise can be completely re-invested in the fulfilment of their mission. An effective business model is essential for the success of a social enterprise in Poland. Review of the literature shows that scientists who have studied new economic activities using business model concepts, agreed with the fact that there is a need to use the patterns of business entities to new hybrid forms of enterprise, in which social utility component is essential. The social enterprises that want to achieve success have to clearly, formulate and develop a business model. The main goal of social business according to Project of 2015 Law on Social Enterprise in Poland is planning to help people with special needs (including social groups at risk of exclusion) to obtain employment (further will be expand to the social, cultural and environmental objectives). New measures to achieve the social value can create new opportunities, but also can modify the existing institutions and norms, which leads "in the loop" feedback and makes entrepreneurship is an interactive process.

Social entrepreneurship in this sense is an intended, purpose-driven activity, based on the records relating to the positive effect of enabling factors (economic and social). Applying of corporate company models to social 
enterprise require a special kind of awareness of the objections that arise when trying to direct application of business models. Very often it turns out that there is a need to build own models of social enterprises, in which the most important factor will be creating of social value. However, there may be irrelevant for social enterprises to analyse patterns resulting from process and holistic models. It should also be noted that in this regard, some of the business process models can be useful for social enterprise. The application of traditional corporate legal solutions for social enterprises is employed in a wide range.

\section{References}

Alter, K.S. (2008). Modele przedsiębiorstw społecznych. In: Antologia kluczowych tekstów. Przedsiębiorstwo społeczne. Ed. J.J. Wygnański. Warszawa: Fundacja Inicjatyw Społeczno-Ekonomicznych.

Antoszkiewicz, J.D. (2002). Przedsiębiorczość w nowej roli. In: B. Piasecki, Przedsiębiorczość i rozwój małych i średnich przedsiębiorstw w XXI wieku. Łódź: Wdawnictwo Uniwersytetu Łódzkiego.

Ashoka Polska. Innowatorzy dla dobra publicznego. (2013). Available at: http://poland.ashoka.org/realizacja-misji (accessed on 11.02.2015).

Balan Vnuk, E. (2013). Social enterprise business models: identifying the trading concepts that inform them. Available at: https://digital. library.adelaide.edu.au/dspace/bitstream/2440/82616/9/01front.pdf (accessed on 15.02.2015).

Bednarczyk, M. (2001). Organizacje publiczne. Zarządzanie konkurencyjnością. Warszawa: Wydawnictwo Naukowe PWN.

Bednarczyk, M. (1996). Otoczenie i przedsiębiorczość w zarządzaniu strategicznym organizacją gospodarczą. Kraków: Wydawnictwo Akademii Ekonomicznej w Krakowie.

Brzóska, J. \& Jerzok, I. (2014). Koncepcje i aplikacje modeli biznesu w organizacjach ekonomii społecznej. Gliwice: Wydawnictwo Politechniki Śląskiej w Gliwicach.

Ćwiklicki, M. (2011). Model tworzenia społecznej wartości. Biuletyn Ekonomia Społeczna w Małopolsce, No. 4. Available at: www. fundacja.e-gap.pl/dokumenty/biuletyn_esm/Biuletyn_ES_nr_4.pdf (accessed on 11.02.2015).

Czemiel-Grzybowska, W. (2010). Zarządzanie przedsiębiorstwem społecznym - raport z badań. Białystok: Regionalny Instytut Społeczno-Ekonomiczny.

Drzewiecki, J. (2011). Model biznesu a strategia organizacji: podobieństwa, różnice. In: Nauki o zarządzaniu. Ed. M. Przybyła. Management Science, No. 8. Wrocław: Wydawnictwo Uniwersytetu Ekonomicznego we Wrocławiu.

Foster, W.L., Kim, P. \& Christiansen, B. (2009). 10 Nonprofit Funding Models. The Stanford Social Innovation Review. 48. Spring 2009.

Frączkiewicz-Wronka, A. (2010). Pomiar efektywności organizacji jako obszar konwergencji metod, narzędzi i instrumentów zarządzania między sektorami biznesowym a publicznym. Gliwice: Wydawnictwo Politechniki Śląskiej w Gliwicach.

Gołębiowski, T., Dudzik, T.M., Lewandowska, M. \& Witek-Hajduk, M. (2008). Modele biznesu polskich przedsiębiorstw. Warszawa: Wydawnictwo Szkoły Głównej Handlowej.

Grewiński, M. \& Wronka, M. (2012). Gospodarka społeczna w UE i w Polsce - między przedsiębiorczością społeczną i CSR. In: A. Frączkiewicz-Wronka, G. Grewiński, Przedsiębiorczość w Polsce - bariery i perspektywy rozwoju. Warszawa: WSP.

Herbst, J. (2006). Kondycja ekonomii społecznej w Polsce 2006. Warszawa: Stowarzyszenie Klon/Jawor.

Kaplan, S. (2013). Modele biznesowe nie są zarezerwowane dla biznesu. Available at: www.hbrp.pl/news.php?id=541 (accessed on 10.03.2015).

Koźmiński, A.K. \& Piotrowski, W. (2005). Zarządzanie. Teoria i praktyka. Warszawa: Wydawnictwo Naukowe PWN.

Kurleto, M. (2014). Innowacyjność w przedsiębiorczości społecznej, a ustawowy zakres filantropii i dobroczynności. In: H. Bieniok, Innowacyjność współczesnych organizacji. Koncepcje i modele. Część l. Katowice: Wydawnictwo Uniwersytetu Ekonomicznego w Katowicach.

Kurleto, M. (2013). The issue of CSR in the development of tourism industry particularly in tourism companies and tourism destinations. In: S. Patrycki, Strategie działań w warunkach kryzysu. Lublin: Wydawnictwo KUL.

Magretta, J. (2013). What Management is? London: Profile Books.

Michelini, L. (2012). Social Innovation and New Business Model Creating Shared Value in Low-Income Markets Heidelberg. New York Dordrecht. London. 
Morris, M.H., Schindehutte, M. \& Allen, J. (2005). The Entrepreneur’s Business Model: Toward a Unified Perspective. Journal of Business Research, 6 (58).

Newth, F. (2012). Business Models and strategic management: A New Integration, Business Expert, New York.

Obłój, K. (2002). Tworzywo skutecznych strategii. Warszawa: Wydawnictwo PWE.

Osterwalder, A. \& Pigneur, Y. (2010). Business Model Generation: A Handbook for Visionaries, Game Changers, and Challengers. New Jersey.

Pynes, E.J. (2011). Effective Non-profit Management: Context and Environment. New York: M.E. Sharpe.

Schimanek, T. Prawo przedsiębiorczości społecznej w Polsce. Available at: www.isp.org.pl/uploads/filemanager/PrawoPST.Schimanek. pdf (accessed on 10.03.2015).

Stevenson, H. \& Jarillo, J. (2007). A Paradigm of Entrepreneurship: Entrepreneurial Management. In: Entrepreneurship: Concepts, Theory and Perspective, Springer Science Business Media.

The Business Process Model. (2004). Sparx Systems UML Tutorials. Available at: www.sparxsystems.com.au/downloads/whitepapers/ The_Business_Process_Model.pdf (accessed on 10.03.2015).

Weerewardena, J. \& Mort, G.S. (2004). Investigating social entrepreneurship: a multidimensional model. Journal of World Businesess, 41 (1).

Wronka, M. (2013). Analyzing the success of social enterprises - critical success factors perspective. In: V. Dermol, N. Trunk Širca, G. Dakovic. Active Citizenship by Knowledge Management \& Innovation, Proceedings of the Management, Knowledge and Learning International Conference 2012. MakeLearn: Cejle.

Cite this article as: Kurleto, M. (2015). An application of the corporate company models for social enterprise (with special emphasis on Polish conditions). Szczecin University Scientific Journal, No. 872. Service Management, 15 (1): 57-65. 
